A Chapter for: Sotarauta, M., and Beer, A. (eds) (forthcoming 2020) The Handbook of City and Regional Leadership, Edward Elgar: Cheltenham

\title{
Old wine in a new bottle: Revisiting organisational conceptions of leadership to understand what place leaders 'actually' do to make things happen
}

\author{
Alyson Nicholds, Staffordshire Business School, Staffordshire University, UK \\ alyson.nicholds@staffs.ac.uk
}

Key words: Organisation Studies; Place Leadership; Critical Reflexivity;

\begin{abstract}
Place Leadership, as 'a specific form of leadership at the urban and regional scale' is considered central to urban and regional growth because it brings together actors from different backgrounds, operating at different scales and with differing levels of power and authority, to work in partnership with others, who may not share their ideological views or business interests. But despite knowing much about what leaders do in organisations and where matters of governance might sit, we've never fully understood 'what it is that place leaders actually do to make things happen at the sub-national scale'. In this chapter, I return to the Organisation Studies literature to see how leadership is 'actually conceptualised' and use this to analyse 'actually existing' case of place leadership, to show how these specific talents, need to differ, in different contexts, in order to get the job done. What this shows, is that, in keeping with Critical Management, it is only through discursive analysis of place leaders' accounts of their practice, that we are able to reveal how these attributes and processes 'actually come together'. This is in keeping with the observations of Beer (2015) that only by acknowledging that regions are construed both materially and discursively through a myriad of processes (Lagendijk 2007) will we succeed in better aligning policy to the specificity of place.
\end{abstract}

$R \& R$ !: notes to editors: Please note that this version has been updated to include a more concise exposition of the salient perspectives on leadership (trait, behaviour and process and how they relate to place leadership) along with greater development of a theoretical frame (psychology, scientific method and discourse) to make sense of where the conceptual confusion might lie. The request to make greater reference to critical theory (I believe) was met in the original brief and underpins critical approaches to discourse (ref: Howarth/Howarth and Torfing) but I have made this more explicit. 
A Chapter for: Sotarauta, M., and Beer, A. (eds) (forthcoming 2020) The Handbook of City and Regional Leadership, Edward Elgar: Cheltenham

\section{Introduction}

"Few accounts of place leadership have found an appropriate balance between structural and individual processes, resulting, on the one hand, in an over-emphasis on the actions of a limited number of charismatic leaders and, on the other hand, in structural analyses blind to the decisions and actions of individuals and groups"

(Sotarauta \& Beer, 2017)

In this chapter, I seek to tackle the problem outlined in the quote above, on the basis that despite being central to the development of urban and regional growth (Ahrend, 2017); and knowing much about what it means to lead in organisations (House \& Aditya, 1997); important questions remain about 'what place leaders actually do to make things happen' at the sub-national scale (Sotarauta 2004; 2007). On the argued basis that place leadership, as a specific form of leadership, does exist at the urban and regional scale (Sotarauta 2009; Sydow, Lerch, Huxham \& Hibbert 2011) and that, given right conditions, it can work to bring together different actors (Ayres, Flinders \& Sandford, 2017; Nicholds, Gibney, Mabey \& Hart 2017), I consider the degree to which this is really about a failure, thus far, to makesense of how different actors use their agency to navigate the complex, relational and valuesoriented contexts involved (Griliitsch \& Sotarauta 2019). In doing so, I ask whether it is actually 'greater dissensus' (rather than shared consensus) that is needed to create the conditions that will turn around ailing areas (Huggins et al, 2018).

Given that "at its most basic level, to study leadership in urban and regional development is to be interested in revealing the things people actually do to influence other people" (Sotarauta, Beer, \& Gibney, 2017), begets a need to return to the Organisational studies literature, to explore how leadership is conceptualised and understood. In doing so, I ask, to what extent place leadership is really just 'old wine in a new bottle', when it seemingly refers to the same organisational conceptions of 'who you are' (character/traits); 'what you do' (behaviours/ skills) and 'where it takes place' (practices/ processes). Hence, I will NOT be repeating well-trodden tropes about the contribution of governance to leadership (Bentley, Pugilis \& Shutt, 2017) or of management to leadership (House and Aditya 1997), rather my enquiry is more philosophical in that I seek to explore the assumptions that underpin how such organisational leadership is done in practice (Zaccarro 2014; Antonakis et al 2012; Yukl 2012) and the types of talents that enable it in this specific context.

Applying these considerations at the sub-national scale, requires greater study of 'leadership in context', something Shelton, Zook \& Wiig (2015) describe as rare but important 'actually existing' cases of place leadership. I approach this task by selecting handpicked 'case examples' both from my own research and others across sectors, to consider in each case, what place leaders have 'actually' done to make things happen in different spaces and places. This is all important because as 'a specific form of leadership at

$R \& R$ !: notes to editors: Please note that this version has been updated to include a more concise exposition of the salient perspectives on leadership (trait, behaviour and process and how they relate to place leadership) along with greater development of a theoretical frame (psychology, scientific method and discourse) to make sense of where the conceptual confusion might lie. The request to make greater reference to critical theory (I believe) was met in the original brief and underpins critical approaches to discourse (ref: Howarth/Howarth and Torfing) but I have made this more explicit. 
the urban and regional scale' (Sotarauta 2009; Sydow, Lerch, Huxham \& Hibbert 2011), place leadership requires actors from different professional backgrounds (Hambleton \& Howard, 2013) who operate at different scales (Bentley, Pugilis \& Shutt, 2017); with different levels of power and authority (Sotarauta 2016, Normann 2013) to work in close partnership (Sotarauta, Horlings \& Liddle, 2012) whilst not necessarily sharing the same ideological views or business interests (Ayres, Flinders \& Sandford, 2017; Nicholds, Gibney, Mabey \& Hart 2017). It begs the question: what type of character, does such a complex feat require and are there specific talents they must they espouse or exhibit?

As part of my foray into the Organisational Studies literature, I seek to evaluate the utility of those scholars operating in a more critical vein (Alvesson, 1996; Alvesson \& Spicer, 2012; Alvesson and Deetz, 2020) and consider the need re-conceptualise this longstanding issue of 'what place leaders do to make things happen' as something of a conceptual and methodological deficit (Zaccaro, 2014; Mango, 2018). I make this claim in the light of critique about the overly positivist nature of leadership research methods in the social sciences which has tended to rely on quantitative and qualitative methods at the expense of more reflexive approaches like discourse (Alvesson, 1996). As I go on to show, by challenging our assumptions about who or what makes an effective place leader, encourages deeper reflection (philosophically) of the type of evidence (epistemologically) needed and approaches best suited (methodologically) to place leadership to turn places places around. This more critically reflexive approach (Nicholds 2013) better fits with the claim that regions are construed both materially and discursively through a myriad of processes Lagendijk (2007) which better supports our efforts to align policy to the specificity of place (Beer, 2015).

With this in mind, we now turn to the leadership studies literature, to outline three key historical strands that have emerged in studies of organisational leadership to consider whether leadership ability comprises 'who you are' (i.e. your immutable character/ traits); 'what you do'(i.e. the behaviour/ skills you use to guide others' performance) or 'how you act' ('i.e. the processes/ practices involved). After discussing the implications of inherent conceptual confusion that arises, I then move to consider different 'cases of actually existing place leadership' from research and writing in the place leadership literature. This is with a view to considering how helpful these organisational conceptualisations of 'place leadership' are in generating knowledge of these specific talents, and how they might better support place leaders in making things happen.

\section{Conceptualising leadership}

Contemporary accounts of leadership in organisations tells us that in spite of longstanding contestation surrounding the concept of leadership (Grint, 2005) and the burgeoning theories 
A Chapter for: Sotarauta, M., and Beer, A. (eds) (forthcoming 2020) The Handbook of City and Regional Leadership, Edward Elgar: Cheltenham

that seemingly serve to underpin it (Mango, 2018 ${ }^{1}$ ), arguably much knowledge has been accumulated about what leadership is and how it's done (House \& Aditya, 1997). For instance, Northouse (2015) is one of many to suggest that when we look at the leadership literature, we can see that whilst there are myriad different ways of viewing leadership, it can be grouped broadly into a series of categories (or conceptual framework) asking: is it "who leaders are' that makes them a leader (i.e. associated with their character/ traits); 'what do leaders do' that makes them a leader (i.e. is it the behaviours they exhibit, such as communicating or problem solving); or has it more to do with the 'process or context' in which leadership takes place? (i.e. as with 'leadership as practice') (See Figure 1 below).

Figure 1: Conceptualising leadership (adapted from Northouse 2015)

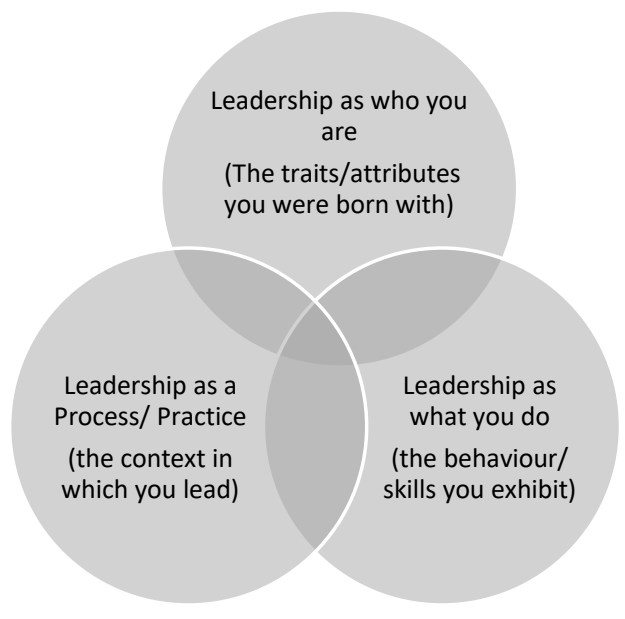

Helpful though a conceptual framework like this is, it is only when we begin to look more deeply at the assumptions underpinning them, that we begin to see why conceptual confusion might exist (Mango, 2018). This is because there remains a gap in understanding about how all of these concepts (trait, behaviour, process) seemingly act together to 'make things happen'. It explains the oft-cited lament that 'the more one learns about leadership, the less one knows' (Grint, 2005). Hence, it suggests that whilst returning to the classical literature might be useful in exploring what is known about the concept of leadership, for it to add value (and not add to the conceptual confusion), it must seek to expose the linkages and provide a coherent whole. This is what we mean by critical reflexivity (Nicholds 2013) and it's something that critical management scholars have long been advocating the need for in plugging gaps in our understanding about how leadership is really done in practice (Alvesson 1996; Alvesson \& Spicer 2012; Alvesson and Deetz 2020).

1

$R \& R$ !: notes to editors: Please note that this version has been updated to include a more concise exposition of the salient perspectives on leadership (trait, behaviour and process and how they relate to place leadership) along with greater development of a theoretical frame (psychology, scientific method and discourse) to make sense of where the conceptual confusion might lie. The request to make greater reference to critical theory (I believe) was met in the original brief and underpins critical approaches to discourse (ref: Howarth/Howarth and Torfing) but I have made this more explicit. 
A Chapter for: Sotarauta, M., and Beer, A. (eds) (forthcoming 2020) The Handbook of City and Regional Leadership, Edward Elgar: Cheltenham

\section{Leadership as character/ trait (who leaders are)}

Perhaps one of the oldest and most well-known theories of leadership is that which is based on an analysis of 'who you are' (House and Aditya 1997). Such trait-based perspectives are rooted in theories of psychology on the basis that whether or not someone can be considered a leader, is dependant largely on their possession of certain character traits (Northouse 2015). Originally, this personality take on leadership was premised on the longheld assumption that because such traits are genetic and immutable (i.e. inherited) (Galton 1869) they could better account for those individuals who had succeeded in achieving 'extraordinary feats' (as with the 'great man theories' of old) (Carlyle 1849). However, the study of trait-based leadership has a long and controversial history because while research shows the possession of traits to be important, it has never been able to reach a consensus about which characteristics (or indeed skills) are essential in guaranteeing leadership success (Kirkpatrick and Locke 1991), as the quote below demonstrates:-

"Key leader traits include: drive (a broad term which includes achievements, motivation, ambition, energy, tenacity, and initiative); leadership motivation (the desire to lead but not to seek power as an end in itself); honesty and integrity; selfconfidence (which is associated with emotional stability); cognitive ability; and knowledge of the business. There is less clear evidence for traits such as charisma, creativity and flexibility. We believe that the key leader traits help the leader acquire necessary skills; formulate an organizational vision and an effective plan for pursuing it; and take the necessary steps to implement the vision in reality" (Kirkpatrick and Locke 1991).

Over time, repeated attempts to isolate the individual differences that distinguish leaders from non-leaders (Antonakis et al, 2012) has led trait-based researchers to focus on identifying central leader 'attributes' (rather than traits); how they link (or not) to outcomes; how they are affected by different situations; and the degree to which these attributes can change over time (Zacarro 2014: 6), as the quote below, shows: -

"leader traits can be defined as relatively coherent and integrated patterns of personal characteristics reflecting a range of individual differences that foster consistent leadership effectiveness across a group and organisational situations" (Zaccaro 2014:7)

Epistemologically, then, by being critically reflexive, it's possible to see how, embedded within these traditional conceptions of trait, are reference to personality theories (in scientific terms) which in turn, implies a link to the 'great man theories' of old which have typically involved the use of more objective forms of empirical analysis (usually historical) involving post-hoc rationalisations of what made a leader great; and leader-centric analysis of the individual traits involved; that these characteristics tended also to be male, adds a well-

$R \& R$ !: notes to editors: Please note that this version has been updated to include a more concise exposition of the salient perspectives on leadership (trait, behaviour and process and how they relate to place leadership) along with greater development of a theoretical frame (psychology, scientific method and discourse) to make sense of where the conceptual confusion might lie. The request to make greater reference to critical theory (I believe) was met in the original brief and underpins critical approaches to discourse (ref: Howarth/Howarth and Torfing) but I have made this more explicit. 
A Chapter for: Sotarauta, M., and Beer, A. (eds) (forthcoming 2020) The Handbook of City and Regional Leadership, Edward Elgar: Cheltenham

known gendered dimension (hence 'great-man' theory). Despite these flaws, Zaccaro (2007), notes the value that combining such character-based analyses can bring (albeit in objectivist/ empiricist terms) to our understandings of how leadership might be done effectively, by enabling the tracing the contribution of key traits/ attributes across place, time and culture. It is this which might explain the continued interest in character as a determinant in distinguishing who might be classed as an able leader, from those who are not, as outlined in the quote below (Zaccaro 2007): -

"Trait approaches dominated the initial decades of scientific leadership research. Later, they were disdained for their inability to offer clear distinctions between leaders and non-leaders and for their failure to account for situational variance in leadership behaviour. Recently, driven by greater conceptual, methodological, and statistical sophistication, such approaches have again risen to prominence. However, their contributions are likely to remain limited unless leadership researchers who adopt this perspective address several fundamental issues. The author argues that combinations of traits and attributes, integrated in conceptually meaningful ways, are more likely to predict leadership than additive or independent contributions of several single traits. Furthermore, a defining core of these dominant leader trait pattern reflects a stable tendency to lead in different ways across disparate organizational domains" (Zacarro 2007).

\section{Leadership as behaviour (what leaders do)}

In keeping with notions of leadership as trait, the idea that leadership might be conceived of in terms of 'what you do' (rather than who you are) stems from decades of research (still on individuals) but with the express aim of identifying how leaders behave (in the context of organisations) to improve the performance of others (usually employees). This way of conceptualising leadership is in marked contrast to theories of trait, because it is situated in context. Hence, the focus is not simply on determining the central attributes that might be driving individual leaders to act, but on how they seek to facilitate others through their leadership behaviour (albeit in an organisational context):-

"The essence of leadership in organisations is influencing and facilitating individual and collective efforts to accomplish shared objectives. Leaders can improve the performance of a team or organisation by influencing the processes that determine performance" (Yukl, 2012: 66).

Epistemologically, as with trait-based approaches, this scientific (rather than psychological) take on leadership is rooted in the assumption that such behaviour must be observable (empirically); measured reliably (using scientific instruments) and be applicable to all leaders. This is important, given our interest in critical reflexivity, as it suggests that the main reason leadership as behaviour is contested is because research has consistently

$R \& R$ !: notes to editors: Please note that this version has been updated to include a more concise exposition of the salient perspectives on leadership (trait, behaviour and process and how they relate to place leadership) along with greater development of a theoretical frame (psychology, scientific method and discourse) to make sense of where the conceptual confusion might lie. The request to make greater reference to critical theory (I believe) was met in the original brief and underpins critical approaches to discourse (ref: Howarth/Howarth and Torfing) but I have made this more explicit. 
A Chapter for: Sotarauta, M., and Beer, A. (eds) (forthcoming 2020) The Handbook of City and Regional Leadership, Edward Elgar: Cheltenham

failed to identify which leadership behaviour leads to which outcomes. This suggests that, as is the case with studies of trait-based leadership (seeking to identify which attributes comprise the leader), despite a large and diverse body of research, it is disagreement (rather than agreement) that reigns in identifying which key behaviours are associated with effective leadership.

For instance, in a major review of studies of effective leadership behaviour from 1950 onwards, Yukl (2012:68) identifies 4 key meta-categories (together with their associated component behaviours) where leadership behaviour has been observed and measured improve performance. So called, 'task-oriented behaviours', mirror those leadership theories that concentrate on structuring work, such as path-goal theory (House 1971) or Hersey and Blanchard's task-relationship behaviour, where leaders can be seen using clarifying; planning, monitoring and problem solving behaviour to manage (some might say control) subordinates' efforts to achieve outcomes. This is clearly demonstrated in Drucker's (1989) 'The practice of management', where leadership effectiveness is conceptualised in terms of setting of objectives, serving as a common language between worker and subordinate. Indeed, so difficult is it to conceptualise such 'leadership as behaviour', that some consider it a process (rather than individual behaviour) because of the degree of followership involved between manager and subordinate (Crossman \& Crossman, 2011):-

"Objectives are the integrating cement of the organisation. Without them, not only planning is impossible, but also no organising, no setting of expectations, no performance measurement, no delegation, no employee development, no meaningful decision-making and no leadership can take place." (Joullie and Spillane 2015:100)

So called 'relations-oriented behaviours' are more in keeping with theories like leader-member exchange or more team-based approaches to leadership, where leaders seek to influence outcomes through supporting, developing, recognising and empowering behaviour. A third category, which comes some-time later, involves 'change-oriented behaviour', incorporating action to advocate, envision, encourage and facilitate innovation and change, as with transformational approaches to leadership. Finally, a fourth meta-category includes 'external monitoring behaviours' (involving networking; external monitoring and representing) thereby connoting the types of advocating roles necessary for leading with strategic purpose in organisations.

However, epistemologically, it is in these continued, leader-centric (singular) and objectivist (empiricist) attempts to define and conceptualise scientifically, 'what behaviour constitutes an effective leader', that we begin to see flaws in this way of conceptualising what leaders do. Not least because researchers have been seen to use different labels to represent the same types of leadership behaviour (which is problematic when using a scientific approach like factor analysis). Methodologically, this results in the development of constructs

$R \& R$ !: notes to editors: Please note that this version has been updated to include a more concise exposition of the salient perspectives on leadership (trait, behaviour and process and how they relate to place leadership) along with greater development of a theoretical frame (psychology, scientific method and discourse) to make sense of where the conceptual confusion might lie. The request to make greater reference to critical theory (I believe) was met in the original brief and underpins critical approaches to discourse (ref: Howarth/Howarth and Torfing) but I have made this more explicit. 
which are not universal (i.e. objective) and which are then used to measure and compare concepts across samples. Methods-wise, there is also the problem of using surveys, the basis of which, relies on the subjective (rather than objective) meaning of the researcher (Yukl 2012). Hence, yet again, as with trait-based theories, what we are seeing here are apparent flaws in the reliance on scientific method (as opposed to psychology) as the basis for confirming evidence of leadership behaviour.

\section{Leadership as discourse (how leaders account for their practice)}

As a branch of organisational studies, critical management studies (Alvesson 1996); Alvesson and Spicer 2012; Alvesson and Deetz 2020) has long drawn on discourse theory to shine a light on the hidden and perhaps less-well explored dimensions of what leaders do (and in some cases, what leaders don't do!) to achieve outcomes. However, in line with other scholars operating within this more critical orientation (Howarth 2000; Howarth and Torfing 2005), debate continues about its essential nature (see Howarth 2000 for an excellent synopsis of the different ways of conceptualising discourse). An in depth discussion is beyond the scope of this chapter, but in essence, this evidence (i.e. accounts of leadership practice) can range from being 'literal' (about observable facts) to 'interpretive' (how leadership acts are framed) or 'dialogic' (how leaders 'see' themselves i.e. identity). As we shall see in the later exposition, the benefits of being able to surface such hidden assumptions, on all levels (functional, interpretive and dialogic) affords much needed clarity about the way that leaders (and place leaders) might use their agency for (often) very different ends.

\section{Functionalist accounts (observing what leaders do)}

On the basis that to be interested in place leadership is to 'observe what leaders do', functionalist accounts of leadership discourse have the capacity to reveal (quite literally) what actors are doing. In this case, the task of analysing what leaders are doing, becomes one of teasing out specific characteristics/ behaviours of the leader involved and trying to ascertain what makes them a good leader (Huggins et al 2018). it could be argued that epistemologically, there is a tendency to objectify leadership as a neutral, observable entity (Law, 2004), that that can be measured objectively (i.e. quantitatively through measures of character, trait) which, in turn allows researchers of leadership asking about how the elements of leadership (trait, behaviour, processes) might be observed empirically.

Interpretive accounts (how leaders frame what they do)

On the basis that different leaders have the capacity to reflect on situations (Williams and May, 1996), interpretive accounts of leadership discourse go beyond these rational accounts of practice to provide socially constructed accounts of what actors say and do (Yanow, 1996: 2000) rather than relying on 'observable' facts. This is because leadership, when looked at through this lens takes account of how people differ in their beliefs and values about situations and how they should be managed. This places knowledge at a wholly contestable level in which $R \& R$ !: notes to editors: Please note that this version has been updated to include a more concise exposition of the salient perspectives on leadership (trait, behaviour and process and how they relate to place leadership) along with greater development of a theoretical frame (psychology, scientific method and discourse) to make sense of where the conceptual confusion might lie. The request to make greater reference to critical theory (I believe) was met in the original brief and underpins critical approaches to discourse (ref: Howarth/Howarth and Torfing) but I have made this more explicit. 
claims about what works are open to multiple interpretations (Fischer and Forrester 1993; Hajer 1993). This puts greater importance on how actors justify what they say (language); the objects they refer to (the resources they draw on); and the acts they have undertaken (what they do) (Yanow, 1996).

Dialogic accounts (how leadership status is ascribed)

A dialogic understanding of leadership differs from an interpretive one because it sees reality as being multiple and emphasising dissensus (disagreement) rather than consensus (agreement). This different way of looking at leadership is useful because it allows us to see how leadership status might be ascribed by others in the form of an identity, which in turn, enables it to 'regulated by others' in the context of past and future assessments of performance (Mabey 2013). This is a powerful concept because it helps us to see how the agency or power embedded in how someone leads is, in reality, shaped by the 'local' context they find themselves (i.e. because leadership practice is embedded in the context in which it occurs) (Fairhurst, 2007). It also helps us to see that, through this more performative lens, leadership can be considered to be 'relational' (i.e. because of how its enacted together with others, as opposed to alone).

Based on my analysis of the three historical strands informing organisational leadership associated with trait/ attributes, behaviour and process, it is possible to produce a table (See Figure 2) outlining the epistemological and methodological assumptions underpinning them. I now use this to draw on 'actually existing' cases of place leadership (Shelton, Zook \& Wiig 2015), with the aim of expounding these concepts more fully in the context of place, to consider the role that place leaders' character'; 'behaviour' and 'process' might play in 'turning around' different places and spaces.

Figure 2: Overview of historical strands of leadership research

\begin{tabular}{|l|l|l|l|l|}
\hline $\begin{array}{l}\text { Conceptualisation } \\
\text { of leadership }\end{array}$ & Underlying assumption & $\begin{array}{l}\text { Period of } \\
\text { dominance }\end{array}$ & Methodological focus & Epistemology \\
\hline $\begin{array}{l}\text { Leadership } \\
\text { Character }\end{array}$ & $\begin{array}{l}\text { Ability to lead depends on } \\
\text { the possession of } \\
\text { genetically inherited traits }\end{array}$ & $\begin{array}{l}19^{\text {th }} \\
\text { Century }\end{array}$ & $\begin{array}{l}\text { Psychology studies of } \\
\text { personality to account for } \\
\text { the achievement of } \\
\text { 'extraordinary feat }\end{array}$ & Positivist \\
\hline $\begin{array}{l}\text { Leadership as } \\
\text { Behaviour }\end{array}$ & $\begin{array}{l}\text { Success in Leadership } \\
\text { depends on improving the } \\
\text { performance of others }\end{array}$ & $20^{\text {th } \text { century }}$ & $\begin{array}{l}\text { Scientific observation of } \\
\text { leadership behaviour using } \\
\text { reliable instruments }\end{array}$ & Empiricist \\
\hline $\begin{array}{l}\text { Leadership as a } \\
\text { Process }\end{array}$ & $\begin{array}{l}\text { Leadership emerges in the } \\
\text { process of leading in } \\
\text { different contexts }\end{array}$ & $21^{\text {st } \text { century }}$ & $\begin{array}{l}\text { Discourse theory to study } \\
\text { different 'accounts of } \\
\text { practice' }\end{array}$ & Constructivist \\
\hline
\end{tabular}

$R \& R$ !: notes to editors: Please note that this version has been updated to include a more concise exposition of the salient perspectives on leadership (trait, behaviour and process and how they relate to place leadership) along with greater development of a theoretical frame (psychology, scientific method and discourse) to make sense of where the conceptual confusion might lie. The request to make greater reference to critical theory (I believe) was met in the original brief and underpins critical approaches to discourse (ref: Howarth/Howarth and Torfing) but I have made this more explicit. 
A Chapter for: Sotarauta, M., and Beer, A. (eds) (forthcoming 2020) The Handbook of City and Regional Leadership, Edward Elgar: Cheltenham

\section{Conceptualising who place leaders are and what they do to make things happen}

Having revisited organisational conceptions of leadership, I now turn to consider the role that place leaders' 'attributes'; 'behaviour' and 'process' might play in turning around ailing areas. However, given what we know about the potential for conceptual confusion in organisational studies, there is a need to remain critically reflexive about the underlying philosophical assumptions when applying them to considerations of place leadership. This is so that we are not become deluded about the capacity of such talents, say in the case of 'traits/ attributes' to their accounting for the achievement of 'extraordinary feats' (Galton 1869)! This implies a need to draw on what Shelton et al (2015) call 'actually existing cases' of place leadership, because they aid our examination of 'what place leaders 'actually' do. We can then begin to ascertain how all of these concepts might come together to produce outcomes for places and spaces. This is important context, since the basic tenets of place leadership suggest a blurring of roles and processes in urban and regional development (Sotarauta and Beer 2016:3) and the need to distinguish those involved in the 'leadership of places' (titular leaders in more formal roles) from those involved with 'leadership in places' (where leadership might emerge more informally) (Collinge and Gibney 2010). These distinctions are important to make when attempting to analyse 'what it is that place leaders do'. This is because not only are the processes formal place leaders employ (such as accountability to institutional hierarchies) likely to differ from that of more informal leaders; but their practice too (with formal leaders having much greater access to resource than informal leaders). Hence, whilst there are some similarities with leadership in organisational contexts, it makes ascertaining how the specific talents of place leaders come into play much more difficult, because the attributes, behaviours and processes needed by different leaders to get the job done, may also differ depending on the context.

\section{How place leaders use 'who they are' to make things happen}

We know implicitly, the importance of character, from our own personal experience of hiring and firing in organisations and as outlined in any person specification, driven by a desire to secure 'great people' who can get the job done (Yukl, 1999). However, we also know from our recent foray into the Organisation Studies literature, that a past reliance on 'traits' in an attempt to distinguish 'leaders from non-leaders' (Kirpatrick and Locke 1991) has led to an over focus on individual leaders (i.e. leader centric) as being heroic and typically male, rendering other more informal types of leadership less significant. Despite this, and as Zacarro (2007, 2014) and Denehy (2008) below, point out, we can't dismiss fully the idea of character counting in the success of leadership, as with the example of 'school nurses', who are seen exhibiting 'the right attributes' to be able to work independently, as well as collaboratively with others, in garnering the interest and respect of other professionals to develop a shared vision (for public health) in the face of a lack of interest or knowledge in others, as the quote below aptly shows:-

$R \& R$ !: notes to editors: Please note that this version has been updated to include a more concise exposition of the salient perspectives on leadership (trait, behaviour and process and how they relate to place leadership) along with greater development of a theoretical frame (psychology, scientific method and discourse) to make sense of where the conceptual confusion might lie. The request to make greater reference to critical theory (I believe) was met in the original brief and underpins critical approaches to discourse (ref: Howarth/Howarth and Torfing) but I have made this more explicit. 
A Chapter for: Sotarauta, M., and Beer, A. (eds) (forthcoming 2020) The Handbook of City and Regional Leadership, Edward Elgar: Cheltenham

\begin{abstract}
"Exhibiting leadership is important for all nurses, but even more so for school nurses who are likely to be the only health care professional in their school(s). In addition, their autonomous role makes it imperative that they are prepared to take the lead in promoting the health of the school community and in creating a healthy school environment. Leaders are able to identify needs and develop an action plan to meet their goals in improving a situation, setting, or policy. They are able to clearly articulate the problem and bring others on board in addressing the identified need"
\end{abstract} (Denehy, 2008)

Hence, when we look at the place leadership literature, one could be forgiven for thinking that character is equally unimportant, with numerous studies instead choosing to focus on the 'relational and processual approaches' that are needed to work in partnership with others when attempting to span the professional or disciplinary divide (Sotarauta and Beer 1996). However, when we look at 'actual cases' of place leadership, as with Denehy's (2008) case, attributes such as drive and emotional intelligence do appear as a strong and central theme. For instance, in my own research with smart city leaders in 6 English cities (Nicholds et al 2017), it is inherent in strategic leaders ${ }^{2}$ own 'accounts of practice', that they need to be 'intelligent mediators' in being able to 'hold the ring' for major policy issues (such as tackling the digital divide) whilst remaining firmly connected to a fixed organisational form themselves (such as a Local Authority or NHS Trust) whilst others who remain bound to their own internal systems of governance. A good 'case-example' of this was given in this same study, by those strategic leaders operating under the state-aid directive, who (unlike their counterparts) who's practice (and capacity) was strictly bound to comply with the regulatory arrangements that prevent governments from unduly intervening in local business markets:-

"Hence, for techno-environmental leadership types, in order for them to tackle the complex, multi-faceted 'wicked' issues they seemingly report, they needed to be socially-oriented, transformational and leader-centric in approach so that they were individually accountable (i.e. 'front-facing') but at the same time able to work relationally across sectors to connect up competing and disparate agendas and integrate different interests over the longer term through collaboration. (Nicholds, Gibney, Mabey \& Hart 2017:256)

This suggests that attributes like 'drive or motivation' may also play an important part in explaining how some place leaders succeed in 'holding the ring' in regional development, as they undertake complex, long-range and cross-disciplinary tasks which require a degree of stamina (Nicholds et al 2017). This is picked up by Soatarauta (2017) as a central asset in

\footnotetext{
${ }^{2}$ we call them techno-environmental in our study owing to their ability as place leaders, to garner technological assets to bridge the digital divide

$R \& R$ !: notes to editors: Please note that this version has been updated to include a more concise exposition of the salient perspectives on leadership (trait, behaviour and process and how they relate to place leadership) along with greater development of a theoretical frame (psychology, scientific method and discourse) to make sense of where the conceptual confusion might lie. The request to make greater reference to critical theory (I believe) was met in the original brief and underpins critical approaches to discourse (ref: Howarth/ Howarth and Torfing) but I have made this more explicit.
} 
A Chapter for: Sotarauta, M., and Beer, A. (eds) (forthcoming 2020) The Handbook of City and Regional Leadership, Edward Elgar: Cheltenham

aiding the implementation of Regional Development Policy, in which it is generally acknowledged, requires a deep commitment to the task of developing the region:-

Almost as a general rule, various actors participate in regional development efforts with the aim to find something for themselves. They do not leave their own interests, drivers, incentives and overseers behind. Thus, it is far from easy to find a common ground for a collective development effort in these kinds of situations. Regional development, and related institutional changes, is essentially about sustained and possibly conflicting encounters of various visions of single organizations, individual interests and a whole range of ideas. Contrary to the common assumption, it is notoriously difficult to construct a shared vision providing a heterogeneous bunch of actors with a sense of direction. Conscious efforts to stimulate the emergence of a regional growth path and construct conditions for it, require agents who work to determine the direction for change through, with and by other actors, and convene and inspire them (Grillitsch and Sotarauta, 2019).

How place leaders use their skills to make things happen

In keeping with organisational studies literature, it is difficult to isolate skills and behaviours that contribute to leadership because it so often, gets tied up with process. This ties into Sotarauta's and Beer's (1996) observation about solving the leadership puzzle, that when 'leadership' gets enacted in complex places and spaces, it represents 'a hidden form of agency' which, unlike more visible forms of governance like institutional structures, it shapes the types of resources that it's possible to access (Sotarauta 2016:45). This highlights the importance of ongoing work, in place leadership, to examine the conceptual links between leadership and governance (Bentley, Pugilis and Shutt 2017); and how this links to power and authority (Sotarauta 2016). Hence, what we see here, is that because of the complex context involved, place leaders are actively working to combine personal 'attributes' (such as intelligence) with processes (like governance) in order to span a disciplinary, organisational and professional divides in order to make things happen.

It is in the course of enacting such governance that Bentley, Pugilis \& Shutt (2017) describe what place leaders are doing when they act as the 'enablers of the growth of spaces', seeking balance through the trinity of their leadership, systems of governance and central-local relations with government. But as with the case above, it is only becomes evident through accounts of practice (rather than empirical observation). As a case example, I present Norman et al (2017) account of practice in the course of enacting regional leadership which shows Nordic political leaders (politicians, academia, firms, non-profit) positioning themselves as 'global green leaders' in order to influence Nordic policy making to drive economic growth and development whilst securing the natural assets on which wellbeing relies. As the quote below outlines, processes of governance relate to the need to broker (to find mutual direction) to overcome conflict and tensions (in this case, diverging positions). $R \& R$ !: notes to editors: Please note that this version has been updated to include a more concise exposition of the salient perspectives on leadership (trait, behaviour and process and how they relate to place leadership) along with greater development of a theoretical frame (psychology, scientific method and discourse) to make sense of where the conceptual confusion might lie. The request to make greater reference to critical theory (I believe) was met in the original brief and underpins critical approaches to discourse (ref: Howarth/Howarth and Torfing) but I have made this more explicit. 
A Chapter for: Sotarauta, M., and Beer, A. (eds) (forthcoming 2020) The Handbook of City and Regional Leadership, Edward Elgar: Cheltenham

Once again, it suggests that it is dissensus (rather than consensus) which frames how place leaders get things done:-

"It follows that regional leadership in a green field must find ways to create meaning of the divergent perspectives inherent within the green economy concept. One challenge...could relate to the tension between the objectives of reducing the industrial environmental impact and the goals of economic growth in a given region. [This\}....relies on processes of that facilitate diverging positions and agendas to find mutual directions for development that can satisfy both economic and environmental concerns" (Henning Norman, Garmann Johnsen, Knudsen, Vasstrom, Garmann Johnsen 2017: 278)

From this example we can see how methodologically, researchers are required to listen to accounts of practice (rather than observe concepts empirically - as with scientific approaches) as evidence of the stories actors tell them about why they did what they did (Forrester, 1993). They are then required to look for patterns in the narratives of actors to see how their particular views become embedded in the institutional machinery over time (Hajer, 1993). What is useful about this more interpretive view of place leadership it's possible to see how different actors construct meaning. Hence, since leadership occurs as a result of a complex web of interactions with others, no-one leader has all the answers (Van den Hooff \& Huysman, 2009:1) This contrasts with more rational accounts of place leadership, because it shows leadership as not being confined to any one individual leader but rather facilitated through the coming together of people sharing a common interest and an environment where mutual trust can be built (Li, 2005); to generate shared goals (Chow and Chan, 2008) and bring together others who have relevant knowledge (Newell \& Swan, 2000). For some theorists, however, this conceptualization of knowledge is still too consensual because it looks for shared patterns of meaning and ignores the fact that people might change their focus or interest when the context changes. Actually-existing cases of this so called 'dialogic' perspective reveals the importance and role of 'leadership identities' as revealed in the example below, where economic development actors, driven by a 'trinity of change' factors associated with their past experience, roles and ability, can be seen enacting their agency to forge networks/ connections that will benefit them in their regional development work:-

"Past experiences and encounters are influenced by the place where individuals are located. Social embedding at the workplace, through recreational and leisure facilities, or other social functions such as childcare and education, contribute to an alignment of perceived opportunities regionally. Localized interactions and learning support the emergence of collective expectations and perceptions of future development opportunities (Grillitsch \& Sotarauta, 2019:11).

$R \& R$ !: notes to editors: Please note that this version has been updated to include a more concise exposition of the salient perspectives on leadership (trait, behaviour and process and how they relate to place leadership) along with greater development of a theoretical frame (psychology, scientific method and discourse) to make sense of where the conceptual confusion might lie. The request to make greater reference to critical theory (I believe) was met in the original brief and underpins critical approaches to discourse (ref: Howarth/Howarth and Torfing) but I have made this more explicit. 


\section{To what extent is place leadership just 'old wine in a new bottle'?}

This chapter began by arguing that despite strong evidence that a specific form of leadership exists at the sub-national scale and of the types of conditions that different actors require to turn ailing places and spaces around, we still know little of the nature of the phenomena called place leadership. The aim of this chapter was then, to draw on literature within the broader organisational studies domain in an attempt to conceptualise and understand 'who leaders are and what they do'. This was with a view to generating knowledge of these specific talents, and how they might better support place leaders in making things happen.

In keeping with the importance of context, these concepts were then considered in the context of 'actually existing' places as a means of questioning the degree to which place leadership is nothing more than 'old wine in a new bottle'? What is clear from this analysis is that whilst place leadership benefits hugely from a return to the organisational studies literature in conceptualising the type of character traits, behaviours/ skills (less so) and processes that we can so clearly being employed by leaders of place (i.e. formal leaders) and leaders in place (informal leaders); what is perhaps different is in its application epistemologically in accounting for what place leaders do to make things happen. Put simply, whilst there are clearly elements of attributes and process (less so, behaviours) at play in what place leaders do to make things happen, it is only possible to actually witness how these concepts come together through leaders' own accounts of their practice.

Perhaps for the first time, what we begin to see is the role that personal attributes, such as those associated with personal 'drive' or 'emotional intelligence' (as referenced in 'intelligent mediator' reference) appear to play in laying the foundations for what 'leaders of place' describe as having to do, in order to 'hold the ring' for complex urban and regional development (such as tackling the digital divide). The need for attributes involving a high level of 'personal drive' comes from having to strike a balance between overseeing the above whilst simultaneously dealing with the more (some might argue) emotional challenges that arise from cross-sectoral working which is more relational in orientation and generates conflict. This is in tandem with the need to navigate institutional requirements, such as ensuring compliance with the state-aid rules which are in place to prevent competition over local markets. There is clearly much more work to be done in surfacing further examples of these and other types of attributes, both in leaders of place (which is what has been focused on here) as well as leaders in place (something which this chapter has not really broached but could easily, given more space and time!). As a way of conceptualising the specific talents that place leaders need to navigate complex spaces, it certainly does more than begin to scratch the surface of the types of attributes and processes place leaders need.

This makes measuring what place leaders do to make things happen, much more of a discursive process (relying on accounts of leadership practice). Hence, in so far that a $R \& R$ !: notes to editors: Please note that this version has been updated to include a more concise exposition of the salient perspectives on leadership (trait, behaviour and process and how they relate to place leadership) along with greater development of a theoretical frame (psychology, scientific method and discourse) to make sense of where the conceptual confusion might lie. The request to make greater reference to critical theory (I believe) was met in the original brief and underpins critical approaches to discourse (ref: Howarth/ Howarth and Torfing) but I have made this more explicit. 
A Chapter for: Sotarauta, M., and Beer, A. (eds) (forthcoming 2020) The Handbook of City and Regional Leadership, Edward Elgar: Cheltenham

rational analysis tells us how place leaders 'actually manage' to bring together actors from across different organisations, operating within different roles, at different scales, across professional backgrounds, we see that it not only ignores the potential differences in interests that actors from different professional backgrounds and sectors might have, but also the highly complex context (institutional and societal) in which place leadership occurs. This, in turn shapes and constrains leadership behaviours and requires the enactment of very different processes and practices. This is important because, when viewed through an interpretive (rather than functionalist) lens as it enable us to make sense of how 'actors interpret policy differently depending on how their professional backgrounds (Fischer \& Forrester 1993, Yanow 1996, 2001, Rein \& Schon 1993). What we haven't seen is evidence of how leadership status is 'ascribed' (and regulated) by others in the form of an identity based on assessments of performance (Mabey, 2013).

What my foray into organisational studies has thus served to reveal, is not only the extent to which "place leadership is fundamentally shaped by context (Gibney, 2014), and is thus highly differentiated in its expression (Nicholds et al, 2017)" and requires the study of 'actually-existing cases' (Shelton, Zook \&Wiig 2015) but the need to consider, through discourse, how the lived experience of such leadership connects the concepts of attributes and process together. In contrast to classical observational studies (which relies on quantitative and qualitative approaches), this can only be done through actors' personal accounts of the leadership actions involved. Doing so requires something of a more reflexive approach, than employed previously, which takes account of the values, beliefs and assumptions of the actors involved.

Methodologically, this places a requirement on us to rethink our approach to studying place leadership and find ways to develop more discursive accounts of leadership, using different methods to capture these seemingly different forms of evidence (Yukl, 2012). Doing so has the capacity to reveal how actors might use framing; identity work and powerbrokering to interpret and shape the outcomes of leadership differently. I discuss the importance of adopting this more pluralistic view of leadership, not least in terms of its relevance to Lagendijk's (2007) previous observation that regions are construed both materially and discursively through a myriad of processes and how this better supports our efforts to align policy to the specificity of place (Beer, 2015) by accounting for how these views come to shape the actions of the different actors involved.

$R \& R$ !: notes to editors: Please note that this version has been updated to include a more concise exposition of the salient perspectives on leadership (trait, behaviour and process and how they relate to place leadership) along with greater development of a theoretical frame (psychology, scientific method and discourse) to make sense of where the conceptual confusion might lie. The request to make greater reference to critical theory (I believe) was met in the original brief and underpins critical approaches to discourse (ref: Howarth/Howarth and Torfing) but I have made this more explicit. 
A Chapter for: Sotarauta, M., and Beer, A. (eds) (forthcoming 2020) The Handbook of City and Regional Leadership, Edward Elgar: Cheltenham

\section{References}

Ahrend, R. (2017) Building better cities: Why national urban frameworks matter, OECD.

Alvesson, M. (1996) Leadership Studies: From procedure and abstraction to reflexivity and situation. The Leadership Quarterly, 7 (4), 455-485.

Alvesson, M and Spicer, A. (2012) Critical Leadership Studies: The case for critical performativity. Human Relations 65 (3) $367-390$.

Alvesson, M and Deetz, S. (2020) Doing critical management research, SAGE:London.

Antonakis, J., Day, D. and Schyns. B. (2012) Leadership and individual differences: At the cusp of a renaissance. The Leadership Quarterly 23: 643-650.

Ayres, S., Flinders, M., \& Sandford, M. (2017). Territory, power and statecraft:

Understanding English devolution. Regional Studies. doi:10.1080/00343404.2017.1360486.

Bentley, J. Pugilis, L., Shutt, J. (2017) Leadership and systems of governance: the constraints on the scope for leadership of place-based development in sub national territories, Regional Studies, 51 (2) 194-209.

Collinge, C. and Gibney, J. (2010) Connecting place, policy and leadership, Policy Studies, 31 (4), 379-391.

Crossman, B., \& Crossman, J. (2011) Conceptualising followership - A review of the literature. Leadership 7 (4): 481-497.

Davoudi, S., Shaw, K., Jamila Haider, L., Quinlan, A., Peterson, G., Wilkinson, C., Fünfgeld, H., McEvoy, D., Porter, L. \& Davoudi, S. (2012): Resilience: A Bridging Concept or a Dead End? Planning Theory \& Practice, 13:2, 299-333.

Denehy, J. Leadership characteristics. The Journal of School Nursing, 24: 107.

Drucker, P. (1989). The practice of management. London: Heinemann

Gibney J., Copeland, S., and Murie, A. (2009) Towards a new strategic leadership of place for the knowledge-based economy, Leadership, 5 (5), 5-22.

$R \& R$ !: notes to editors: Please note that this version has been updated to include a more concise exposition of the salient perspectives on leadership (trait, behaviour and process and how they relate to place leadership) along with greater development of a theoretical frame (psychology, scientific method and discourse) to make sense of where the conceptual confusion might lie. The request to make greater reference to critical theory (I believe) was met in the original brief and underpins critical approaches to discourse (ref: Howarth/ Howarth and Torfing) but I have made this more explicit. 
A Chapter for: Sotarauta, M., and Beer, A. (eds) (forthcoming 2020) The Handbook of City and Regional Leadership, Edward Elgar: Cheltenham

Gibney, J., Hart, D., Mabey, C., and Nicholds, A. (2014) Smart Leadership for smart cities: Leadership foundations for smart city practitioners, Unpublished.

Gibney, J. and Nicholds, A. (2020) Reimagining place leadership for social purpose. Sotarauta, M., and Beer, A. (eds) (forthcoming 2020) The Handbook of City and Regional Leadership, Edward Elgar: Cheltenham

Grint, K. (2005) Leadership: Limits and Possibilities, Basingstoke: Palgrave Macmillan. Hartley, J. (2002). Leading communities. Leadership and Organisation Development Journal, 23(9), 419-429. doi:10. 1108/01437730210449311

Grillitsch, M. and Sotarauta, M. (2019) Trinity of change agency, regional development paths and opportunity spaces. Progress in Human Geography, 1-20.

Krogh, G., Nonaka, I. and Rechsteiner, L. (2012) Leadership in Organisational Knowledge Creation: A Review and Framework, Journal of Management Studies, 49 (1), 240-277.

Hambleton, R. and Howard, J. (2013) Place-Based Leadership and Public Service Innovation, Local Government Studies, 39 (1), 47-70.

Healy, P. (2010) Making better places: The planning project in the twenty first century. Basingstoke: Palgrave Macmillan.

Horlings, I. and Liddle, J. (Eds) (2012) Leadership and Change in Sustainable Regional Development, Abingdon, Routledge.

House, R.J. (1971) A path-goal theory of leader effectiveness. Administrative Science Quarterly, 16: 321-339.

House, R. J, and Aditya, R. (1997) The social scientific study of leadership: Quo Vadis? Journal of Management 201623 (3) 409-473 https://doi.org/10.1177/014920639702300306

Howarth, D. (2000) Discourse: Concepts in the social science. Open University Press: Buckingham.

Howarth, D., \& Torfing, J.(eds) (2005) Discourse Theory in European Politics: Identity, Policy and Governance. Palgrave Macamillan: Basingstoke.

Huggins, R., Thompson, P., and Obschonka, M. (2018) Human Behaviour and economic growth: A psychological perspective on local and regional development. Environment and 
A Chapter for: Sotarauta, M., and Beer, A. (eds) (forthcoming 2020) The Handbook of City and Regional Leadership, Edward Elgar: Cheltenham

Planning A: Economy and Space 2018, 50 (6): 1269-1289. DOI:

$\underline{10.1177 / 0308518 X 18778035}$

Joullie, J. E. and Spillane, R. (2015) Heroic Drucker. Journal of Business Ethics 128: 95-105.

Kirkpatrick. S.A. and Locke, E. A (1991) Leadership: Do traits matter? Academy of Management Perspectives, 5 (2) https://doi.org/10.5465/ame.1991.4274679

Knorr-Cetina, K. (1999) Epistemic Cultures: How the Sciences Make Knowledge, Cambridge, Mass, Harvard University Press.

Lagendijk, A. (2007) The accident of the region: A strategic relational perspective on the construction of the region's significance. Regional Studies 41 (9): 1193-1208.

DOI: $10.1080 / 00343404.2015 .1033178$

Mabey, C. and Freeman, T. (2010) Reflections on leadership and place. Policy Studies 31 (4) 505-522.

Mabey, C. \& Nicholds, A. (2015) Discourses of knowledge across global networks: What can be learnt about place leadership from the ATLAS collaboration? International Business

Review, Volume 24, Issue 1, February 2015, Pages 43-54.

https://www.sciencedirect.com/science/article/pii/S0969593114000754

Mango, E. (2018) Rethinking Leadership Theories. Open Journal of Leadership, 7, 57-88. doi: 10.4236/oj1.2018.71005.

Nicholds, A., Gibney, J., Mabey, C., \& Hart, D. (2017). Making sense of variety in place leadership. Regional Studies, 51(2), 249-259. doi:10.1080/00343404.2016.1232482

Normann, R. (2013) Regional Leadership: A systemic view. Systemic Practice and Action Research, 26 (1), 23-38.

Norman, H., Johnsen, Knudsen, Vasstrom, Johnsen (2017) Emergence of regional leadership - a field approach. Regional Studies, 51 (2): 273-284

Northouse, P.G. (2015). Leadership: Theory \& Practice, 7th edition, Sage

Shelton, T., Zook, M. and Wiig, A. (2015) The 'actually existing smart city', Cambridge Journal of Regions, Economy and Society 2015, 8, 13-25.

$R \& R$ !: notes to editors: Please note that this version has been updated to include a more concise exposition of the salient perspectives on leadership (trait, behaviour and process and how they relate to place leadership) along with greater development of a theoretical frame (psychology, scientific method and discourse) to make sense of where the conceptual confusion might lie. The request to make greater reference to critical theory (I believe) was met in the original brief and underpins critical approaches to discourse (ref: Howarth/Howarth and Torfing) but I have made this more explicit. 
A Chapter for: Sotarauta, M., and Beer, A. (eds) (forthcoming 2020) The Handbook of City and Regional Leadership, Edward Elgar: Cheltenham

Sotarauta, M. (2009). Power and influence tactics in the promotion of regional development. Geoforum; Journal of Physical, Human, and Regional Geosciences, 400, 895905.

Sotarauta, M., Horlings, I. and Liddle, J. (Eds) (2012) Leadership and Change in Sustainable Regional Development, Abingdon, Routledge.

Sotarauta, M. (2014) Reflections on 'Mobilizing leadership in cities and regions', Regional Studies, Regional Science, (1), 1, 28-31.

Sotarauta, M. (2016) Place Leadership, governance and power. Administration 64 (3/4), 45 58.

Sotarauta, M. (2016) Leadership and The City: Power, Strategy and Networks in the Making of Knowledge Cities, Abingdon, Routledge.

Sotarauta, M. and Beer, A. (2017) Governance, agency and place leadership: Lessons from a cross-national analysis, Regional Studies, DOI 10.1080/00343404.2015.1119265

Sotarauta, M., Beer, A. and Gibney, J. (2017) Making sense of leadership in urban and regional development. Regional Studies 51 (2): 187-193.

Sydow, J., Lerch, F., Huxham, C. and Hibbert, P. (2011) A silent cry for leadership: Organizing for leading (in) clusters, Leadership Quarterly, 22 (2), 328-343.

Yukl, G. (1999) An Evaluation of Conceptual Weaknesses in Transformational and Charismatic Leadership Theories. Leadership Quarterly, 10, 285-305.

http://dx.doi.org/10.1016/S1048-9843(99)00013-2

Yukl, G. (2008) How leaders influence organizational effectiveness, The Leadership Quarterly, 19, 708-23

Yukl, G. (2012) Effective Leadership Behaviour: What we know and what questions need more attention. Academy of Management Perspectives, 16 (4): 66-85.

Zaccaro, S. (2007) Trait-based perspectives of leadership. American Psychologist, 62 (1), Jan 2007:6-16.

Zacarro, S..J. (2014) Leadership memes: From ancient history and literature to twenty first century theory and research. In: Day, D. (2014) The Oxford Handbook of Leadership and Organisations. Oxford University Press: Buckingham.

$R \& R$ !: notes to editors: Please note that this version has been updated to include a more concise exposition of the salient perspectives on leadership (trait, behaviour and process and how they relate to place leadership) along with greater development of a theoretical frame (psychology, scientific method and discourse) to make sense of where the conceptual confusion might lie. The request to make greater reference to critical theory (I believe) was met in the original brief and underpins critical approaches to discourse (ref: Howarth/Howarth and Torfing) but I have made this more explicit. 